\begin{tabular}{l|l} 
Twice Monthly & 24 \\
\hline
\end{tabular} $10 / 1 / 2020$

7. Complete Masing Address of Kno

1 Liberty Plaza

New York NY 10006

Cambridge University Press

(

9. Ful Names and Complete Maling Addresses of Publisher, Edhor, and Managing Edtoc (Do not teave blank)

Cambridge University Press

1 Liberty Plaza

New York, NY 10006

Ediboc (Name and complete maling addross)

Garry L Messing

ity, USA

Maraging Edhor (Name and completete maling addiresses)

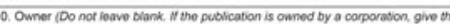

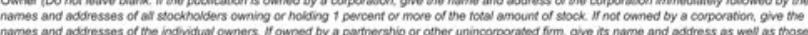

Full Name

complete Maling Adoriss

\begin{tabular}{l|l}
\hline & S06 Keystone Drive \\
\hline & Warrendale, PA 15086-7537
\end{tabular}

\begin{tabular}{l|l}
\hline & \\
\hline & \\
\hline &
\end{tabular}

11. Known Bondholders, Mortgageas, and Other Socunty Holders Oming or Holding 1 Parcent or More of Total Amount of Bonds. Morgages.

\begin{tabular}{l|l}
\hline Full Name & Complete Mailing Addross \\
\hline & \\
\hline & \\
\hline & \\
\hline &
\end{tabular}

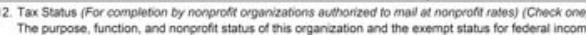

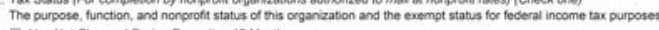

C. Has Nor Changoc Dunng precocing 12 Monow

Phisher must submit expianewion of change weth mis statements 13. Publication Tribe

Journal of Materials Research

15. Extent and Nature of Circulation

UGUST 2020

\begin{tabular}{|c|c|c|}
\hline & $\begin{array}{l}\text { Each lissue During } \\
\text { Preceding } 12 \text { Months }\end{array}$ & $\begin{array}{l}\text { Issue Publilished } \\
\text { Nearest to Filing Date }\end{array}$ \\
\hline a. Total Number of Copies (Net press run) & 190 & 122 \\
\hline
\end{tabular}

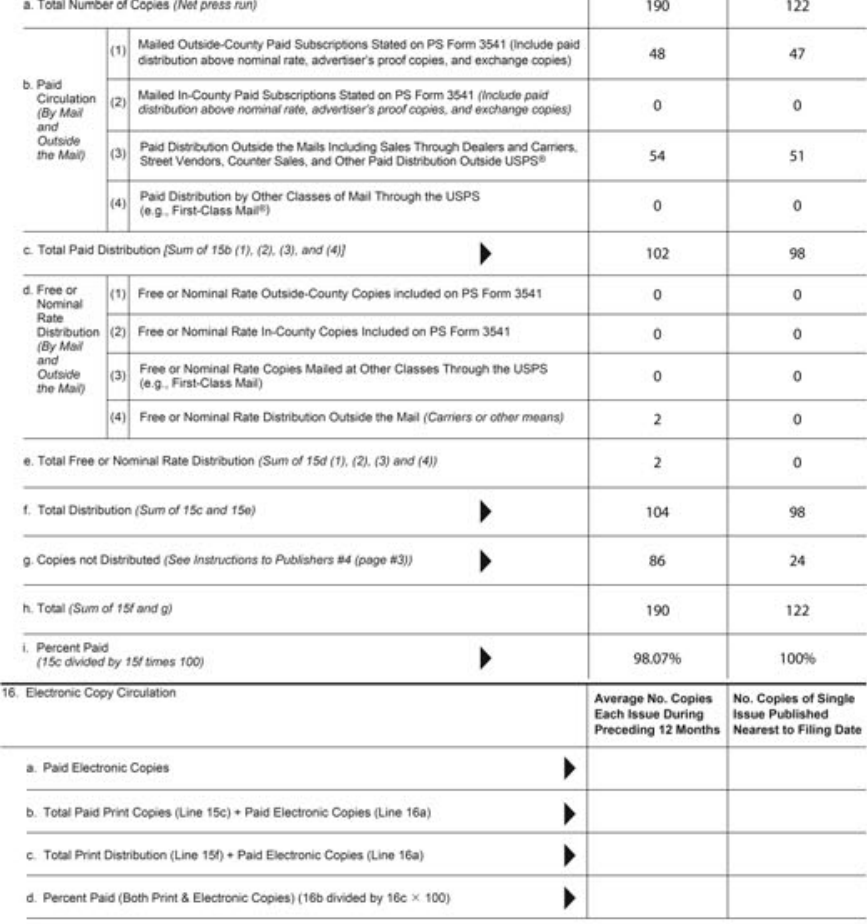

XI centily that 50\%, of all my distributed copies (electronic and print) are paid above a nominal price.

17. Publicascon of Statement or Omnershio

8 It the publication is a general publicason, publicaton of this statement is required. Wa be printed $\quad \square$ Publication not required.

in the October issue of this pubitcation

18. Signature and Tibe of Eotor, Publisher, Business Manager, or Owner

Nina lammatteo 


Grand Patrons
RICHARD K. BAMBACH
ARTHUR J. BOUCOT
RODNEY M. FELDMAN AND CARRIE SCHWEITZER
ROBERT AND ELVIRA GASTALDO
THE FAMILY OF N. GARY LANE
A. R. (PETE) PALMER
J. WILLIAM SCHOPF
RAMAN J. SINGH
STEVEN M. STANLEY
Patrons
EDWARD J. ANDREW, JR.
WILLIAM I. AUSICH
BRUCE M. BELL
STIG M. BERGSTROM
DAVID J. BOTTJER
DONALD W. BOYD
DEREK E. G. BRIGGS
JAMES C. BROWER
ANDREW M. BUSH
JOHN L. CARTER
PETER R. CRANE
THE CUSHMAN FOUNDATION
WILLIAM A. DIMICHELE
J. ROBERT DODD
MARY L. DROSER
LUCY E. EDWARDS
ROBERT J. ELIAS
J. MARK ERICKSON
DOUGLAS H. ERWIN
HOWARD R. FELDMAN
ROBERT M. FINKS
KARL W. FLESSA
TERRENCE J. FREST
PHILIP D. GINGERICH
BRIAN F. GLENISTER
F. D. (BUD) HOLLAND, JR.
J. STEWART HOLLINGSWORTH
NIGEL C. HUGHES
THOMAS W. KAMMER
ERLE G. KAUFFMAN
PATRICIA H. KELLEY
SUSAN M. KIDWELL
SOSA

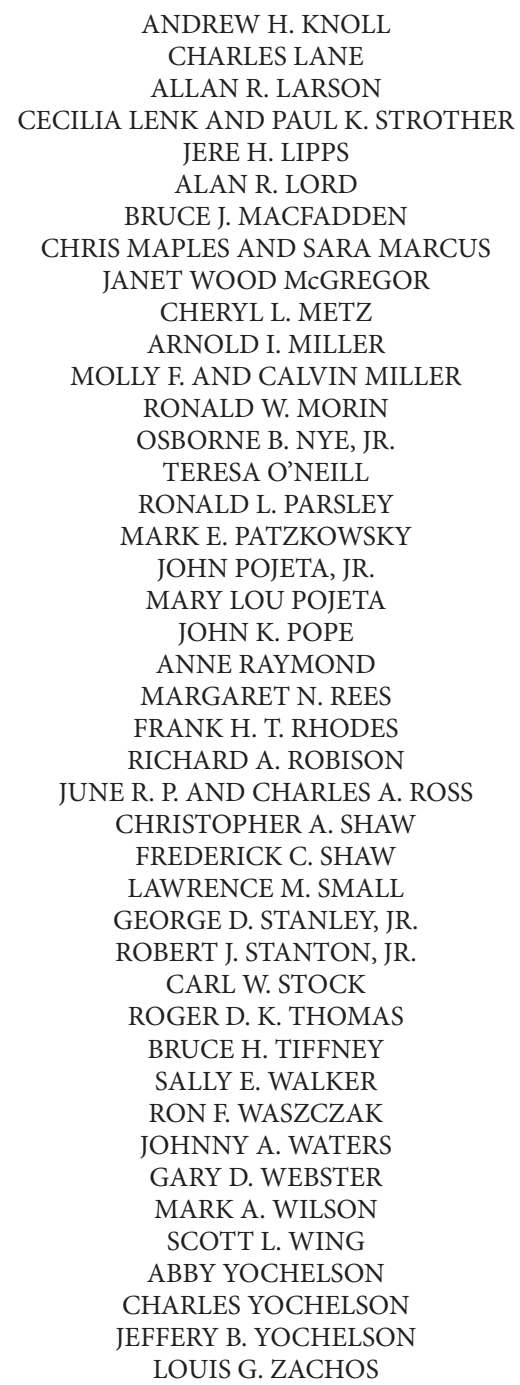

ANDREW H. KNOLL

K AND PAUL K STROTHER

JERE H. LIPPS

BRUCE J. MACFADDEN

JANET WOOD McGREGOR

CHERYL L. METZ

OLLY F. AND CALVIN MILLER

RONALD W. MORIN

JOHN POJETA, JR.

MARY LOU POJETA

FRANK H. T. RHODES

CHRISTOPHER A. SHAW

FREDERICK C. SHAW

LAWRENCE M. SMALL

CARL W. STOCK

ROGER D. K. THOMAS

RON F. WASZCZAK

HNNY A. WATERS

SCOTT L. WING

LOUIS G. ZACHOS

The Journal of Paleontology publishes manuscripts on all aspects of paleontology, including systematics, phylogeny, paleoecology, paleobiogeography, biostratigraphy, taphonomy, and evolution. It emphasizes specimen-based research and features illustrations of the highest quality possible. Manuscript treating all fossil organism groups are welcome, including invertebrates, vertebrates, plants, algae, and microorganisms of all sorts, as well as ichnofossils (trace fossils).

The Journal of Paleontology accepts only online manuscript submissions through the website:

https://mc.manuscriptcentral.com/paleo

Author guidelines can be downloaded at:

https://www.cambridge.org/core/journals/journal-of-paleontology/information/instructions-contributors

For questions regarding online submissions, please contact the editorial offices at:

journalofpaleontology@cambridge.org

Membership Information

Members of the Paleontological Society automatically receive electronic subscriptions to Paleobiology and the Journal of Paleontology as a benefit of membership. To apply for individual membership, please go to the Paleontological Society's homepage at http://paleosoc.org/ where links to an electronic application, a printable paper application form, and a complete list of membership benefits are provided under the Membership heading. 


\section{JOURNAL of PALEONTOLOGY}

\section{VOL 95 I NO 1 I JANUARY 2021}

$1 \quad$ Lijing Liu, Yasheng Wu, Hongping Bao, Hongxia Jiang, Lijing Zheng and Yanlong Chen Diversity and systematics of Middle-Late Ordovician calcified cyanobacteria and associated microfossils from Ordos Basin, North China

24 Anna V. Koromyslova and Petr V. Fedorov

The oldest bifoliate cystoporate and two other bryozoan taxa from the Dapingian (Middle Ordovician) of north-western Russia

40 Xiaolin Duan, Yue Liang, Lars E. Holmer and Zhifei Zhang

First report of acrotretoid brachiopod shell beds in the lower Cambrian (Stage 4) Guanshan Biota of eastern Yunnan, South China

56

Jorge Colmenar and Eben Blake Hodgin

First evidence of Lower-?Middle Ordovician (Floian-?Dapingian) brachiopods from the Peruvian Altiplano and their paleogeographical significance

75 B. Gudveig Baarli

Plectatrypinae and other ribbed atrypides succeeding the end Ordovician extinction event, Central Oslo Region, Norway

106 Jan Ove R. Ebbestad, Dennis R. Kolata and Mare Isakar

New onychochilid mollusks from the Middle and Upper Ordovician of Baltica and Laurentia

123 Luis Collantes, Eduardo Mayoral, Eladio Liñán and Rodolfo Gozalo

Atopidae (Trilobita) in the upper Marianian (Cambrian Series 2, Stage 4) of Iberia

133 Dionizio A. Moura-Júnior, Sandro M. Scheffler, Felipe F. F. Moreira, André Nel and

Gabriel Mejdalani

First record of a shore bug (Insecta, Hemiptera, Saldidae) from Gondwana

141 Sandro M. Scheffler

Crinoids from the Lower (Pragian-Emsian) and Middle (early Eifelian) Devonian of Bolivia (Icla and Belén formations, Malvinokaffric Realm)

154 Daniel B. Blake and James Sprinkle

Arceoaster hintei n. gen. n. sp., a late Silurian homeomorphic asteroid (Echinodermata, Hudsonasteridae)

162 Scott Melnyk, Stephen Packer, John-Paul Zonneveld and Murray K. Gingras

A new marine woodground ichnotaxon from the Lower Cretaceous Mannville Group, Saskatchewan, Canada

170 Eric J. Hilton, Lance Grande and Fan Jin

Redescription of † Yanosteus longidorsalis Jin et al., 1995 (Chondrostei, Acipenseriformes,

†Peipiaosteidae) from the Early Cretaceous of China

184 Massimo Delfino, Àngel H. Luján, Juan Abella, David M. Alba, Madelaine Böhme, Alejandro Pérez-Ramos, Emanuel Tschopp, Jorge Morales and Plini Montoya

Late Miocene remains from Venta del Moro (Iberian Peninsula) provide further insights on the dispersal of crocodiles across the late Miocene Tethys

193 William W. Korth, Clint A. Boyd, Robert J. Emry and Jeff J. Person

Marsupials (Mammalia, Metatheria) from the Brule Formation (Whitneyan, Oligocene) North Dakota

205 David K. Loydell

Lenzograptus, a new name for the graptolite Lenzia Rickards and Wright, 1999

\section{Cambridge Core}

For further information about this journal please

go to the journal website at:

cambridge.org/jpa 